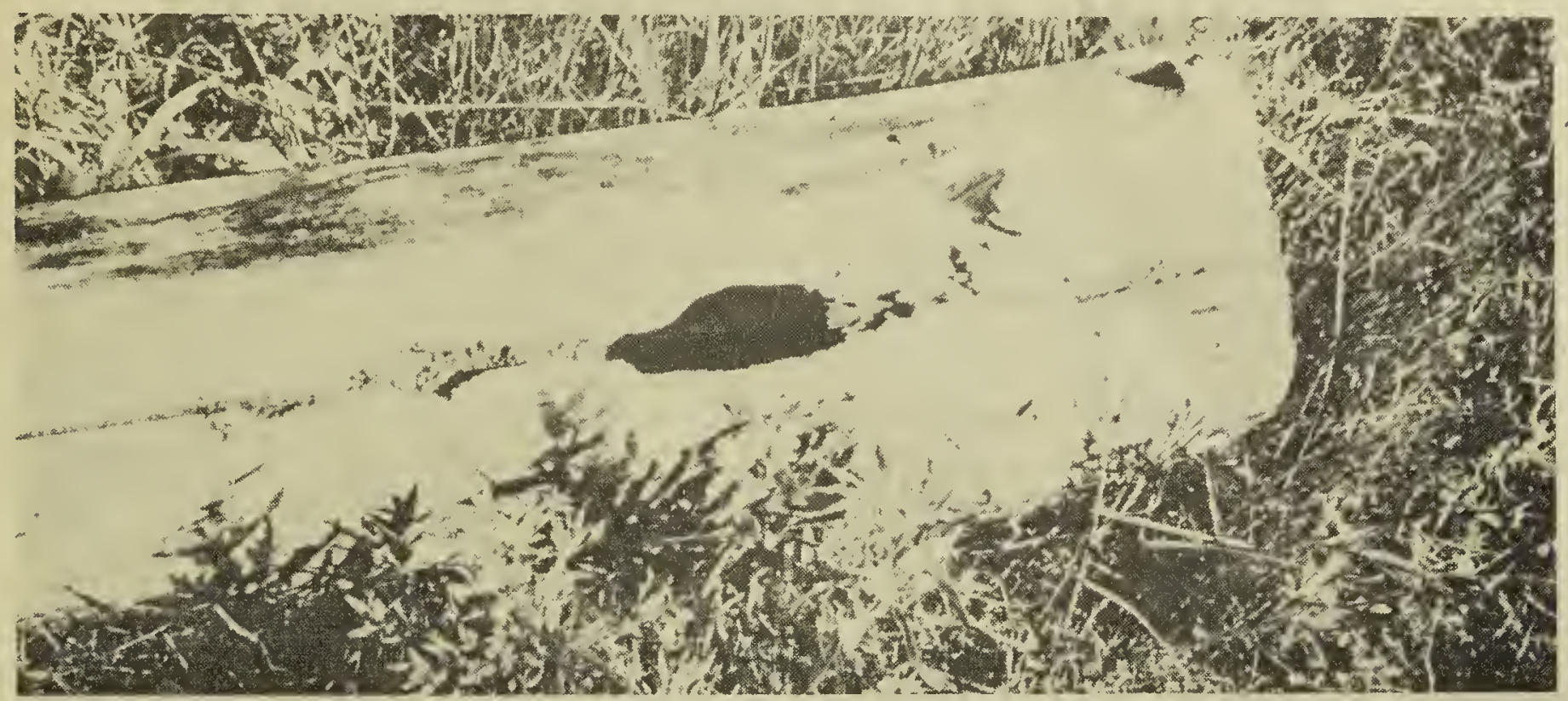

Hollow log on ground occupied by Flicker. Dilke.

previously had constituted a small island several hundred yards from shore. This practically converted one pair of crows into mariners, for their nest had three feet of water beneath it. On June 28, we anchored the boat at the base of the tree and climbed up to band the almost full-grown young. One of them jumped overboard, but when he struck the water he became even more frightened. He did not swim in the conventional manner, but rather used his outstretched wings as oars. He apparently chose us as the lesser of the two evils and came directly back to the boat and clambered over the side. I placed a band on his leg and put him back on the nest.

\section{A GALA YEAR}

\section{ELIZABETH HUBBARD, Grenfell}

Wild flowers had a gala year here. Things ordinarily seen singly appeared as masses of bloom. In one or two places lilies made quite a show and they were to be seen along most roadsides. A small flowered white Aster is blooming profusely in my perennial border now. I think it is the Many-flowered. A Willow Aster also can be depended on for a big patch of colour there every fall.

A $n$ American Bittern which nests in a nearby slough, takes flights across our yard on the way to the dug-out. When he does the small birds evidently mistake him for a hawk and give him the works.

\section{Observe the Hawk}

By MRS. M. BROOKER

Grassy Lake, P.O. Love, Sask.

When the sound of the shot had faded and the few feathers settled slowly to the ground, we walked over to where the hawk sprawled face down, his wings spread as if in the last living moment he had prepared for flight into some other skies beyond.

He was a goshawk, powerful, splendidly beautiful. Surely the millions of years development in the making of this fierce flesh eater were not without purpose. Yet some people shoot hawks indiscriminately without first specifying what type of hawk they down.

The Redtail lines his nest with grey squirrel tails. We can safely agree that the tails of imperfect and diseased squirrels are among them.

The goshawk flushes or downs his prey in a flash of speed. The sick or maimed have no chance against this attack. Of course he gets the perfect ones too, but since he is partly responsible for their perfection, should he not enjoy his innings? So you will counterattack and ask, how does he happen to be so perfect? What natural enemy banishes the weak and maimed in his family? None that we know of. But providence takes care of that. If the hawk is not swift, sure, and ferocious at birth he will die shortly after the parent hawks stop feeding him, thus never able to propagate his imperfections. 